Zagazig Veterinary Journal

Volume 44, Number 2, p 91-100, September, 2016

CFaculty of Veterinary Medicine, Zagazig University, 44511, Egypt

DOI: $10.21608 / z v j z .2016 .7851$.

\title{
Bacteriological Quality Assessment of Some Locally Manufactured Dairy Desserts Sold in Beni-Suef City, Egypt and Molecular Detection of Staphylococcus aureus Enterotoxin \\ Genes
}

Gamal M. Hassan ${ }^{1 *}$ and Samia I. Afifi ${ }^{2}$

${ }^{1}$ Food Hygiene Department, Faculty of Veterinary Medicine, Beni-Suef University, Egypt

${ }^{2}$ Microbiology Department, Animal Health Research Institute, Beni-Suef, Egypt

Article History: Received: 3/8/2016 Received in revised form: 17/8/2016 Accepted: 3/9/2016

\begin{abstract}
Seventy-five randomly collected samples of ice-cream, rice with milk and mehallabeia (25, each) from different localities in Beni-Suef city, Egypt, were bacteriologically examined. The mean values of aerobic plate, Coliforms, Fecal coliforms, E. coli, Enterococci, Bacillus cereus and Staphylococcus aureus counts/g in the examined ice-cream samples were $7.02 \times 10^{5} \pm 4.93 \times 10^{5}$, $1.45 \times 10^{5} \pm 3.21 \times 10^{4}, 9.58 \times 10^{2} \pm 4.6 \times 10^{2}, 1.35 \times 10^{2} \pm 66,8.12 \times 10^{4} \pm 4.61 \times 10^{4}, 1.17 \times 10^{4} \pm 4.59 \times 10^{3}$ and $1.51 \times 10^{4} \pm 9.13 \times 10^{3}$, while, in rice with milk samples they were $5.52 \times 10^{4} \pm 2.78 \times 10^{4}, 3.52 \times$ $10^{3} \pm 1.94 \times 10^{3}, \quad 1.66 \times 10^{2} \pm 1.56 \times 10^{2}, 4.8 \pm 3.1, \quad 1.28 \times 10^{4} \pm 6.25 \times 10^{3}, \quad 2.38 \times 10^{5} \pm 1.4 \times 10^{5}$ and $6.32 \times 10^{2} \pm 2.96 \times 10^{2}$, respectively. In mehallabeia samples, the counts were $6.07 \times 10^{4} \pm 3.6 \times 10^{4}$, $6.59 \times 10^{3} \pm 2.6 \times 10^{3}, \quad 1.6 \times 10^{2} \pm 89, \quad 9.48 \pm 8, \quad 2.6 \times 10^{4} \pm 1.64 \times 10^{4}, \quad 3.83 \times 10^{5} \pm 3.27 \times 10^{5} \quad$ and $4.89 \times 10^{2} \pm 3.28 \times 10^{2}$, respectively. Amplification of enterotoxigenic associated genes using multiplex PCR, showed that sea and see genes were detected in all the examined coagulase positive $S$. aureus isolates. In conclusion, strict hygienic measures should be followed during production and handling of milk products with health educational programs for producers and handlers.
\end{abstract}

Keywords: Dairy desserts, Bacteriological examination, sea, see

\section{Introduction}

Dairy desserts are popular products worldwide, usually formulated with milk, sugar, modified starch, hydrocolloids such as carrageenan, flavorings and colorants [1,2]. The most widely consumed dairy desserts in Egypt are ice-cream, rice with milk and mehallabeia. Dairy-based foods are important vehicles for the transmission of various pathogens especially in countries where hygienic standards are not strictly enforced [3]. Contaminated milk and its products may harbor a variety of microorganisms which are responsible for many food-borne outbreaks such as Coliforms, Fecal coliforms, E. coli, Enterococci, Bacillus cereus and Staphylococcus aureus [4-8].

Staphylococcus aureus is considered the second or third most common pathogen responsible for outbreaks of food poisoning in many countries [9]. Strains of S. aureus can produce one or more staphylococcal enterotoxins (SEs), which cause food poisoning in humans [10]. Up to date, 21 staphylococcal enterotoxins (SE) or enterotoxin-like proteins (SEls) have been identified [11]. On the basis of antigenic characters, Staphylococcal enterotoxins are classified into five main serological types characterized by the initials SEA, SEB, SEC, SED and SEE [11,12].

The common feature of SEs is high stability and resistance towards most proteolytic enzymes, such as pepsin or trypsin, allowing protection of their activity in the gastrointestinal tract [13]. The SEs also retain their biological activities even after pasteurization [14]. The objectives of this study were to evaluate the bacteriological quality of some dairy desserts (ice-cream, rice with milk and mehallabeia) consumed in Beni- 
Suef city, Egypt as well as the molecular detection of some enterotoxigenic associated genes in $S$. aureus isolates using multiplex PCR. to verify the quality of these products.

\section{Material and Methods}

\section{Collection and preparation of samples}

Seventy-five samples of dairy desserts including ice-cream, rice with milk and mehallabeia (25, each) were randomly collected from different localities at Beni-Suef city, Egypt. The collected samples were directly transferred aseptically in sterile bags to the laboratory with a minimum of delay to be examined.

\section{Preparation of samples}

Eleven grams of each sample were thoroughly mixed and transferred to a sterile wide-mouth container containing $99 \mathrm{~mL}$ of sterile saline and they were mixed until a homogenous dispersion was obtained to reach a dilution of 1:10, from which ten-fold serial dilutions were prepared [15].

\section{Bacteriological examination}

The bacteriological quality of the prepared samples was evaluated by the determination of the aerobic total colony count using standard plate count agar at $35^{\circ} \mathrm{C}$ for $48 \pm 3 \mathrm{~h}$, also, the total coliform count by Most Probable Number method using Lauryl Sulphate Tryptose broth and Brilliant-green Lactose Bile broth $2 \%$ at $35 \pm 1^{\circ} \mathrm{C}$ for $24 \mathrm{~h}$ was determined [15]. Fecal coliform count by Modified Eijkman's test using EC broth at $45.5^{\circ} \mathrm{C} \pm 0.2$ for $24 \pm 2 \mathrm{~h}$ was also carried out [16]. Escherichia coli true fecal type was isolated and identified using Eosine Methylene Blue agar (EMB) at $35^{\circ} \mathrm{C}$ for $24 \mathrm{~h}$ were carried out according to AOAC [17]. Enterococci count using Kanamycin Aesculin Azide agar at $42{ }^{\circ} \mathrm{C}$ for 18-24 h [18] and enumeration and isolation of $B$. cereus using Polymyxin Pyruvate Egg Yolk Mannitol Bromothymol Blue agar (PEMBA) which incubated at $37{ }^{\circ} \mathrm{C}$ for $24 \mathrm{~h}[16,18]$. Moreover, enumeration and isolation of coagulase positive $S$. aureus using Baired Parker's agar at $37^{\circ} \mathrm{C}$ for $24 \mathrm{~h}[19,20]$.

\section{Detection of enterotoxigenic genes in $S$. aureus using multiplex PCR}

Three coagulase positive $S$. aureus isolates recovered from ice-cream, rice with milk and mehallabeia (one isolate, each) were used for the detection of enterotoxigenic associated genes using multiplex PCR [21].

Genomic DNA from three coagulase positive $S$. aureus isolates was extracted using the QIAamp DNA Mini kit (Qiagen, Germany, $\mathrm{GmbH}$ ) according to the manufacturer guidelines. Specific primers for the amplification of the five major enterotoxin associated genes were synthesized by Metabion Company, Germany, and the sequences are listed in Table (1).

The reaction was performed in a total volume of $50 \mu \mathrm{l}$ containing $25 \mu \mathrm{L}$ of Emerald Amp Max PCR Master Mix (Takara, Japan), $1 \mu \mathrm{L}$ of each primer $(20 \mathrm{pmol}), 5 \mu \mathrm{l}$ of molecular water, and $10 \mu \mathrm{L}$ of template DNA. The reaction conditions included initial denaturation $\left(94^{\circ} \mathrm{C}\right.$ for $\left.5 \mathrm{~min}\right), 35$ cycles (denaturation at $94^{\circ} \mathrm{C}$ for $30 \mathrm{sec}$; annealing at $50^{\circ} \mathrm{C}$ for $45 \mathrm{sec}$; extension at $72^{\circ} \mathrm{C}$ for $45 \mathrm{sec}$ ) and final extension at $72^{\circ} \mathrm{C}$ for 10 minutes [21].

Ten $\mu \mathrm{L}$ of the amplified PCR product was analyzed by electrophoresis in $1.5 \%$ agarose gel (Applichem, Germany, GmbH) stained with $0.5 \mu \mathrm{g}$ of ethidium bromide/mL (Sigma). Electrophoresis was carried out in $1 \mathrm{X}$ TAE buffer using gradients of $5 \mathrm{~V} / \mathrm{cm}$ for 1 hour. DNA molecular size marker (100 bp ladder) (Qiagen, Germany, $\mathrm{GmbH}$ ) was used to determine the fragment sizes. The gel was visualized and photographed by a gel documentation system (Alpha Innotech, Biometra). 
Table (1): Oligonucleotide sequences of primers for the amplification of five enterotoxin associated genes in $S$. aureus isolates

\begin{tabular}{|c|c|c|}
\hline Target gene & Primers sequences (5'-3') & $\begin{array}{l}\text { Amplified segment } \\
\text { (bp) }\end{array}$ \\
\hline sea & $\begin{array}{l}\text { GGTTATCAATGTGCGGGTGG } \\
\text { CGGCACTTTTTTCTCTTCGG }\end{array}$ & 102 \\
\hline seb & $\begin{array}{l}\text { GTATGGTGGTGTAACTGAGC } \\
\text { CCAAATAGTGACGAGTTAGG }\end{array}$ & 164 \\
\hline sec & $\begin{array}{l}\text { AGATGAAGTAGTTGATGTGTATGG } \\
\text { CACACTTTTAGAATCAACCG }\end{array}$ & 451 \\
\hline sed & $\begin{array}{l}\text { CCAATAATAGGAGAAAATAAAAG } \\
\text { ATTGGTATTTTTTTTCGTTC }\end{array}$ & 278 \\
\hline see & $\begin{array}{l}\text { AGGTTTTTTCACAGGTCATCC } \\
\text { CTTTTTTTTCTTCGGTCAATC }\end{array}$ & 209 \\
\hline
\end{tabular}

\section{Results and Discussion}

The results recorded in Table (2) showed that the aerobic plate counts (APC) ranged from $1 \times 10^{2}$ to $1.1 \times 10^{7}$ with a mean value of $7.02 \times 10^{5} \pm 4.93 \times 10^{5}$ in the examined ice-cream samples. While, in the rice with milk samples APC ranged from $1 \times 10^{2}$ to $6 \times 10^{5}$ with a mean value of $5.52 \times 10^{4} \pm 2.78 \times 10^{4}$ (Table 3 ). In mehallabeia samples, APC ranged from $2.3 \times 10^{2}$ to $9 \times 10^{5}$ with a mean value of $6.07 \times 10^{4} \pm 3.6 \times 10^{4}$ (Table 4). Similar results were recorded by Abdel-Haleem et al. [22] and Al-Gendi [23]. Higher results for icecream were recorded by El-Bagoury [24] and Sobeih et al. [25].

The high aerobic plate counts reflect the inferior quality of raw materials and ingredients used in manufacturing of these products, insufficient heat-treatment, post heat-treatment contamination as well as unhygienic conditions during production.

Table 2: Statistical analytical results of bacterial counts in examined ice-cream samples

\begin{tabular}{lcccccl}
\hline Count & $\begin{array}{c}\text { Number of } \\
\text { Samples }\end{array}$ & \multicolumn{2}{c}{ Positive samples } & \multicolumn{2}{c}{ Counts / g } \\
\cline { 2 - 6 } & 25 & No. & \% & minimum & maximum & Mean \pm SEM \\
\hline APC & 25 & 23 & 100 & $1 \times 10^{2}$ & $1.1 \times 10^{7}$ & $7.02 \times 10^{5} \pm 4.93 \times 10^{5}$ \\
Coliforms & 25 & 15 & 62 & $<3$ & $4.3 \times 10^{5}$ & $1.45 \times 10^{5} \pm 3.21 \times 10^{4}$ \\
Coliforms & 25 & 15 & 60 & $<3$ & $9 \times 10^{3}$ & $9.58 \times 10^{2} \pm 4.6 \times 10^{2}$ \\
E. coli & 25 & 16 & 64 & $<3$ & $1.5 \times 10^{3}$ & $1.35 \times 10^{2} \pm 66$ \\
Enterococci & 25 & 10 & 40 & $<100$ & $1.1 \times 10^{6}$ & $8.12 \times 10^{4} \pm 4.61 \times 10^{4}$ \\
B. cereus & 25 & 13 & 52 & $<100$ & $7.3 \times 10^{4}$ & $1.17 \times 10^{4} \pm 4.59 \times 10^{3}$ \\
S. aureus & & & & & $2 \times 10^{5}$ & $1.51 \times 10^{4} \pm 9.13 \times 10^{3}$ \\
\hline
\end{tabular}

The examination of dairy products for coliforms is highly recommended for their significance as indicator organisms for the unhygienic measures adopted in dairy industries. Moreover, the high number of coliforms is objectionable as it renders these products to be considered of an inferior quality. Regarding the results recorded in Table (2), coliforms could be detected in $92 \%$ of the examined ice-cream samples with counts ranged from $<3$ to $4.3 \times 10^{5}$ with a mean value of $1.45 \times 10^{5} \pm 3.21 \times 10^{4}$, while, $48 \%$ of rice with milk samples ranged from $<3$ to $4 \times 10^{4}$ with a mean value of $3.52 \times 10^{3} \pm 1.94 \times 10^{3}$ (Table 3 ) and also in $52 \%$ mehallabeia samples it ranged from $<3$ to $4.33 \times 10^{4}$ with a mean value of $6.59 \times 10^{3} \pm 2.6 \times 10^{3}$ (Table 4). Nearly similar results for ice-cream and rice with milk were recorded by Al-Gendi [23] who also reported 
higher rates for mehallabeia. Lower isolation rates and counts for rice with milk and mehallabeia were reported by Abdel-Haleem et al. [22] who detected higher results for icecream. Moreover, lower isolation rates and higher counts for ice-cream were recorded by El-Bagoury [24]. The presence of high number of Coliforms in the examined samples is considered to be an efficient indicator for fecal contamination and therefore, the possibility of presence of hazardous organisms. Moreover, it can indicate the use of poor quality ingredients and /or the absence of heat-treatment and sanitization during processing. Even when good hygienic measures are adopted during the manufacture of these dairy products, contamination might occur during the packaging of the finished product or even due to careless handling, storage and distribution [16].

Table 3: Statistical analytical results of bacterial counts in examined rice with milk samples

\begin{tabular}{lcccccc}
\hline \multirow{2}{*}{ Count } & $\begin{array}{c}\text { Number of } \\
\text { Samples }\end{array}$ & \multicolumn{2}{c}{ Positive samples } & \multicolumn{2}{c}{ Counts / g } \\
\cline { 2 - 7 } & 25 & No. & \% & minimum & maximum & Mean \pm SEM \\
\hline APC & 25 & 12 & 400 & $1 \times 10^{2}$ & $6 \times 10^{5}$ & $5.52 \times 10^{4} \pm 2.78 \times 10^{4}$ \\
Coliforms & 25 & 4 & 16 & $<3$ & $4 \times 10^{4}$ & $3.52 \times 10^{3} \pm 1.94 \times 10^{3}$ \\
Coliforms & 25 & 4 & 16 & $<3$ & $3.9 \times 10^{3}$ & $1.66 \times 10^{2} \pm 1.56 \times 10^{2}$ \\
E. coli & 25 & 10 & 40 & $<3$ & 70 & $4.8 \pm 3.1$ \\
Enterococci & 25 & 12 & 48 & $<100$ & $1.1 \times 10^{5}$ & $1.28 \times 10^{4} \pm 6.25 \times 10^{3}$ \\
B. cereus & 25 & 11 & 44 & $<100$ & $5.6 \times 10^{6}$ & $2.38 \times 10^{5} \pm 1.4 \times 10^{5}$ \\
S. aureus & & & & & & $6.32 \times 10^{2} \pm 2.96 \times 10^{2}$ \\
\hline APC. Aerobic Plate Count
\end{tabular}

Fecal coliforms could be detected in $60 \%$ of the examined ice-cream samples with counts ranged from $<3$ to $9 \times 10^{3}$ with a mean value of $9.58 \times 10^{2} \pm 4.6 \times 10^{2}$, while, $16 \%$ of the examined rice with milk samples contained coliforms with counts ranged from $<3$ to $3.9 \times 10^{3}$ with a mean value of $1.66 \times 10^{2}$ $\pm 1.56 \times 10^{2}$ (Tables 2 and 3 ). In $24 \%$ of mehallabeia samples, fecal coliforms count ranged from $<3$ to $2.1 \times 10^{3}$ with a mean value of $1.6 \times 10^{2} \pm 89$ (Table 4). Relatively similar findings were recorded by Abdel-Haleem et al. [22] for ice-cream and mehallabeia who cited higher results for rice with milk, also, higher results recorded by Al-Gendi [23] for icecream, rice with milk and mehallabeia.

The presence of fecal coliforms in a dairy product indicates either direct or indirect fecal contamination because it is a common inhabitant in the intestinal tract of humans and animals. Moreover, there is a close link between $E$. coli and possibly enteric pathogens. Also, the presence of fecal coliforms may be attributed to poor quality ingredients, ineffective sanitization, unhygienic storage and carelessness during handling and distribution [16].

Table 4: Statistical analytical results of bacterial counts in examined mehallabeia samples

\begin{tabular}{|c|c|c|c|c|c|c|}
\hline \multirow[t]{2}{*}{ Count } & \multirow{2}{*}{$\begin{array}{c}\text { Number of } \\
\text { samples }\end{array}$} & \multicolumn{2}{|c|}{ Positive samples } & \multicolumn{3}{|c|}{ Counts / g } \\
\hline & & No. & $\%$ & minimum & maximum & Mean \pm SEM \\
\hline APC & 25 & 25 & 100 & $2.3 \times 10^{2}$ & $9 \times 10^{5}$ & $6.07 \times 10^{4} \pm 3.6 \times 10^{4}$ \\
\hline Coliforms & 25 & 13 & 52 & $<3$ & $4.33 \times 10^{4}$ & $6.59 \times 10^{3} \pm 2.6 \times 10^{3}$ \\
\hline Coliforms & 25 & 6 & 24 & $<3$ & $2.1 \times 10^{3}$ & $1.6 \times 10^{2} \pm 89$ \\
\hline E. coli & 25 & 6 & 24 & $<3$ & $2 \times 10^{2}$ & $9.48 \pm 8$ \\
\hline Enterococci & 25 & 12 & 48 & $<100$ & $4 \times 10^{5}$ & $2.6 \times 10^{4} \pm 1.64 \times 10^{4}$ \\
\hline B. cereus & 25 & 12 & 48 & $<100$ & $8.2 \times 10^{6}$ & $3.83 \times 10^{5} \pm 3.27 \times 10^{5}$ \\
\hline S. aureus & 25 & 4 & 16 & $<100$ & $7 \times 10^{3}$ & $4.89 \times 10^{2} \pm 3.28 \times 10^{2}$ \\
\hline
\end{tabular}


As illustrated in Table (2) E. coli was detected in $60 \%$ of ice-cream samples with counts ranged from $<3$ to $1.5 \times 10^{3}$ with a mean value of 1 . $35 \times 102 \pm 66$. While, in $16 \%$ of rice with milk samples $E$. coli count ranged from $<3$ to 70 with a mean value of $4.8 \pm 3$.1 (Table $3)$. In $24 \%$ of mehallabeia samples it ranged from $<3$ to $2 \times 10^{2}$ with a mean value of $9.48 \pm 8$ (Table 4).

Abdel Haleem et al. [22] isolated E. coli from $40 \%, 24 \%$ and $20 \%$ with counts $<10^{4}$, $<10^{2}$ and $<10$ in ice cream, rice with milk and mehallabeia samples, respectively. Al-Gendi [23] isolated E. coli from $20 \%$, $0 \%$ and $4 \%$ with counts $<10^{4},<3$ and $<10^{2}$ in ice cream, rice with milk and mehallabeia samples, respectively. In addition, Mohammed et al. [26] isolated E. coli from $13.3 \%$ of ice cream samples.

The results given in Table (2) showed that enterococci were detected in $64 \%$ of ice-cream samples with count ranged from $<100$ to $1.1 \times 10^{6}$ with a mean value of $8.12 \times 10^{4}$ $\pm 4.61 \times 10^{4}$. While, $40 \%$ rice with milk samples contained enterococci count ranged from $<100$ to $1.1 \times 10^{5}$ with a mean value of $1.28 \times 10^{4}$ $\pm 6.25 \times 10^{3}$ (Table 3 ). In $48 \%$ of mehallabeia samples it ranged from $<100$ to $4 \times 10^{5}$ with a mean value of $2.6 \times 10^{4} \pm 1.64 \times 10^{4}$ (Table 4).

Abdel Haleem et al. [22] reported that $53.3 \%$ of the examined mehallabeia samples were contaminated by enterococci with a count less than 100/g and in $48 \%$ of rice with milk samples with a count below $100 / \mathrm{g}$. In addition, $86.6 \%$ of ice-cream samples were contaminated by enterococci with a count varied from 10 to $6.4 \times 10^{4}$ with a mean count of $8.1 \times 10^{3}$ [22].

The obtained high values of enterococci reflect the poor sanitary practices during manufacturing, handling, storage and distribution as its occurrence is considered as an indicator of fecal matter contamination. Also, these high numbers could constitute a public health hazard and may induce food poisoning [16].
The results recorded in Tables (2 and 3) showed that B. cereus was detected in $40 \%$ of ice-cream samples with a range of $<100$ to $7.3 \times 10^{4}$ with a mean count of $1.17 \times 10^{4}$ $\pm 4.59 \times 10^{3}$, while in $48 \%$ of rice with milk samples it ranged from $<100$ to $2.6 \times 10^{6}$ with a mean value of $2.38 \times 10^{5} \pm 1.4 \times 10^{5}$. In addition, $48 \%$ of mehallabeia samples, $B$. cereus count ranged from $<100$ to $8.2 \times 10^{6}$ with a mean value of $3.83 \times 10^{5} \pm 3.27 \times 10^{5}$ (Table 4 ).

Hussien et al. [27] isolated B. cereus form $55 \%$ of ice-cream samples with a count ranging from $2 \times 10^{6}$ to $3 \times 10^{10}$ with a mean count of $3.1 \times 10^{9}$. Lower results (16 and $4 \%$ ) were recorded by Altaf et al. [28] and Maryam et al. [29], respectively. The high percentage of $B$. cereus may be attributed to fraud of the product with starch which is a favorable medium for $B$. cereus organisms or due to insufficient heating during the product manufacturing [27].

Similar results were reported by ALAshmawy et al. [30] for mehallabeia while higher results were recorded by Hussien et al. [27].

Examining foods for $S$. aureus aims to confirm that these organisms may be the causative agent of foodborne illness, to determine whether the product or its ingredients are the potential source of $S$. aureus food poisoning and to demonstrate post-processing contamination which mainly due to defect in the personal hygiene or exposure of the food to inadequately sanitized food processing surfaces [16].

The results recorded in Table (2) showed that $S$. aureus was detected in $52 \%$ of icecream samples with a range of $<100$ to $2 \times 10^{5}$ with a mean count of $1.51 \times 10^{4} \pm 9.13 \times 10^{3}$. In $44 \%$ of rice with milk samples the count ranged from $<100$ to $5.6 \times 10^{3}$ with a mean value of $6.32 \times 10^{2} \pm 2.96 \times 10^{2}$ (Table 3 ). While, in $16 \%$ of mehallabeia samples it ranged from $<100$ to $7 \times 10^{3}$ with a mean value of $4.89 \times 10^{2} \pm 3.28 \times 10^{2}$ (Table 4$)$. 
Regarding ice-cream, the results recorded by Hussein et al. [27] showed the isolation of $S$. aureus from $15 \%$ of the samples with a count ranged from $1,9 \times 10^{3}$ to $2 \times 10^{6}$ with a mean count of $6.7 \times 10^{5}$. Mathews et al. [31] isolated S. aureus from $18.7 \%$ of ice-cream samples. Similar results $(40 \%, 50 \%$ and $50 \%)$ were recorded by Abdel Hameed and EL-Malt [32], Fadel and Ismail [33] and Zakary et al. [34], respectively. However, higher results were recorded by El Bagoury [24] and Sobeih et al. [25] respectively. In addition, Hussein et al. [27] couldn't detect $S$. aureus in mehallabeia samples.

Similar results for rice with milk (35 and $66.7 \%$ ) were recorded by Sina et al. [35] and Tang et al. [36], respectively, while, lower results (6.9 and 15\%) were recorded by Cho et al. [37] and Hussein et al. [27], respectively.
Egyptian standards (1993) recommended that ice cream must be free from $S$. aureus, while WHO [39] stated that $S$. aureus should not increase than $10 \mathrm{CFU} / \mathrm{g}$. Also IDF [40] stated that the number of $S$. aureus in frozen milk based products should not exceed 100 $\mathrm{CFU} / \mathrm{g}$. S. aureus is the leading cause of foodborne intoxication (minimum infection dose $10^{5}-10^{7} \mathrm{CFU} / \mathrm{g}$ or $1-20 \mu \mathrm{g}$ enterotoxin per person) [41].

In the current study, three coagulase positive $S$. aureus isolates recovered from ice cream, rice with milk and mehallabeia (one, each) were used in order to detect the classical enterotoxin associated genes (sea, seb, sec, sed and see) using multiplex PCR. The results demonstrated that, sea and see genes were found in the three investigated isolates (Figure $1)$.

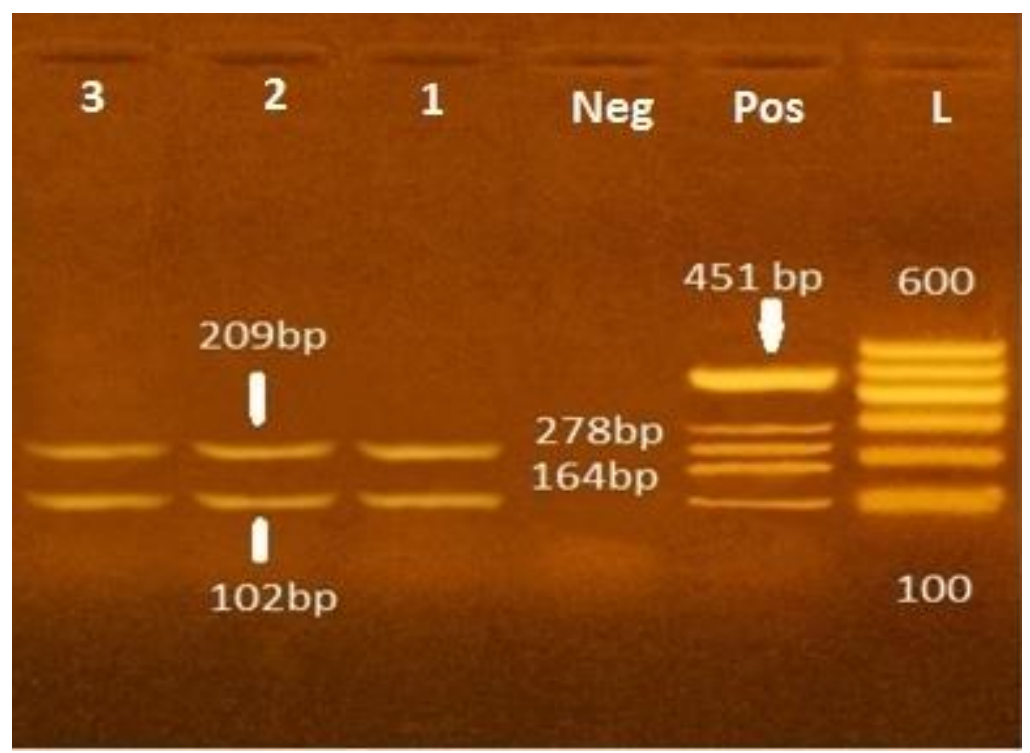

Figure 1: Agarose gel electrophoresis patterns of multiplex PCR amplification products for $S$. aureus enterotoxin associated genes. Lane L, DNA molecular size marker (100 bp ladder), Lane Pos., control positive mixed strains for classical enterotoxins in S. aureus A, B, C, D and E prepared by the National Laboratory for Veterinary Quality Control on Poultry, Dokki, Giza, Lane Neg., control negative strain for classical enterotoxins in $S$. aureus (A, B, C, D and E), lanes 1 to 3, PCR amplicons for three coagulase positive $S$. aureus isolates recovered from ice-cream, rice with milk and mehallabeia samples. The three isolates had both sea and see enterotoxin associated genes at $102 \mathrm{bp}$ and $209 \mathrm{bp}$, respectively.

Recent studies have reported that most $S$. aureus strains isolated from milk and dairy products harbored more than one toxin gene $[42,43]$. Similar findings were reported by Mathenge et al. [9] who concluded that out of the screened $270 \mathrm{~S}$. aureus isolates, sea $(61.8 \%)$ was the most frequently detected gene, followed by see (33.1\%). Madahi et al. [44] reported that the most commonly detected gene in 27 S. aureus isolates was sea (25\%), 
but no see gene was detected. The differences in the frequency of enterotoxin associated genes in $S$. aureus might be attributed to the origin of the isolates, which could vary between animals, humans, foods or environment [9]. The role of SEs in staphylococcal food poisoning is still not clear in most parts of the world; further studies are needed to assess the role they play in $S$. aureus food-poisoning.

\section{Conclusion}

From this study it is concluded that sanitary measures during manufacturing, handling and distribution of milk based desserts used for human consumption in BeniSuef city are neglected. Most examined samples are highly contaminated rendering them of inferior quality and unfit for human consumption exposing the consumers to health hazards. Therefore, strict hygienic measures should be followed during production and handling of these products with health educational programs for producers and handlers.

\section{Conflict of interest}

The author declares no conflict of interest.

\section{References}

[1] De Wijk, R.A.; van Gemert, L.J.; Terpstra, M.E.J. and Wilkinson, C.L. (2003): Texture of semi-solids, sensory and instrumental measurements on vanilla custard desserts. Food Qual Prefer, 14(4): 305-317.

[2] González-Tomás, L. and Costell, E. (2006): Relation between consumers' perception of color and texture of dairy desserts and instrumental measurements using generalized procrustes analysis. J Dairy Sci, 89(12): 4511-4519.

[3] Meyer-Broseta, S.; Diot, A.; Bastian, S.; Riviere, G. and Cerf, O. (2003): Estimation of low bacterial concentration: Listeria monocytogenes in raw milk. Int J Food Microbiol, 80(1): 115.
[4] Danielsson-Tham, M.L.; Eriksson, E.; Helmersson, S.; Leffler, M.; Ludtke, L.; Steen, M; Sørgjerd, S. and Tham, W. (2004): Causes behind a human cheeseborne outbreak of gastrointestinal listeriosis. Foodborne Pathog Dis, 1(3):153-159.

[5] MacDonald, P.D.; Whitwam, R.E.; Boggs, J.D.; MacCormack, J.N.; Anderson, K.L. Reardon, J.W.; Saah, J.R.; Graves, L.M.; Hunter, S.B. and Sobel, J. (2005): Outbreak of Listeriosis among Mexican immigrants as a result of consumption of illicitly produced Mexican-style cheese. Clin Infect Dis, 40(5): 677-682.

[6] Makino, S.I.; Kawamoto, K.; Takeshi, K.; Okada, Y.; Yamasaki, M.; Yamamoto, S. and Igimi, S. (2005): An outbreak of food-borne Listeriosis due to cheese in Japan, during 2001. Int J Food Microbiol, 104(2): 189-196.

[7] Okwumabua, O.; O'Connor, M.; Shull, E.; Strelow, K.; Hamacher, M.; Kurzynski, T. and Warshauer, D. (2005): Characterization of Listeria monocytogenes isolates from food animal clinical cases: PFGE pattern similarity to strains from human listeriosis cases. FEMS Microbiol Letters, 249(2): 275-281.

[8] Oliver, S.P.; Jayarao, B.M. and Almeida, R.A. (2005): Food-borne pathogens in milk and the dairy farm environment: food safety and public health implications. Foodborne Pathog Dis, 2(2):115129

[9] Mathenge, J.M.1.; Okemo, P.O.; Ng'ang'a, P.M.; Mbaria, J.M.; Gicheru, M.M. (2015): Identification of enterotoxigenic Staphylococcus aureus strains from meat and dairy products by multiplex PCR and reverse passive latex agglutination test in Nairobi, Kenya. East and central Africa Med J, 2: 97-103.

[10] Al-Jumaily, E.F.; Saeed, N.M.; Hussain, H. and Khanaka, H.H. (2014): Detection of enterotoxin types produced by 
coagulase positive Staphylococcus species isolated from mastitis in dairy cows in Sulaimaniyah region. Appl Sci Report, 2(1):19-26.

[11] Schelin, J.; Wallin-Carlquist, N.; Thorup Cohn, M.; Lindqvist, R. and Barker, G.C. (2011): The formation of Staphylococcus aureus enterotoxin in food environments and advances in risk assessment. Virulence, 2(6): 580-592.

[12] Loncarevic, S.; Jørgensen, H.J.; Løvseth, A.; Mathisen, T. and Rørvik, L.M. (2005): Diversity of Staphylococcus aureus enterotoxin types within single samples of raw milk and raw milk products. J Appl Microbiol, 98(2): 344350.

[12] Clarisse, T.; Michèle, S.; Olivier, T.; Valérie, E. Jacques-Antoine, H.; Michel, G. and Florence, V. (2013): Detection and quantification of staphylococcal enterotoxin A in foods with specific and sensitive polyclonal antibodies. Food Control, 32(1): 255- 261.

[13] Asao, T.; Kumeda, Y.; Kawai, T.; Shibata, T.; Oda, H.; Haruki, K.; Nakazawa, H. and Kozaki, S. (2003): An extensive outbreak of staphylococcal food poisoning due to low-fat milk in Japan: Estimation of enterotoxin A in the incriminated milk and powdered skim milk. Epidemiology and infection, 130(1): 33-40.

[14] American Public Health Association "A.P.H.A." (1992): Standard methods for the examination of dairy products. $16^{\text {th }}$ ed., A.P.H.A. New York.

[14]International Committee on Microbiological Specifications for Food "I.C.M.S.F." (1978): Microorganisms in foods. I. Their significance and methods of enumeration. $2^{\text {nd }}$ ed. University of Toronto Press, Toronto, Buffalo and London.

[15] Association of official analytical chemists "A.O.A.C." (1975): Official methods of analysis. $12^{\text {th }}$ ed. Po. Box 450, Benjamin Franklin Station Washington.

[16] Mossel, D. A. A.; Bijker, P. G. H. and Felderink, I. (1978): Arch Lebensmittel HJg. 29, 121-127.

[17] Clark, W.S. and Nelson, F.E. (1961): Multiplication of coagulase positive Staphylococci in grade A raw milk sample. J Dairy Sci, 44(2):232-236.

[18] Thatcher, F.S. and Clark, D.S. (1975): Microorganisms in foods. International Committee on microbiological specification for foods. Univ. of Toronto Press, Toronto and Buffalo, Canada.

[19] Mehrotra, M.; Wang, G. and Johnson, W.M. (2000): Multiplex PCR for detection of genes for Staphylococcus aureus enterotoxins, exfoliative toxins, toxic shock syndrome toxin 1, and methicillin resistance. J Clinic Microbiol, 38(3):1032-1035.

[20] Amal, A.A.; Moustafa, M.K. and Ahmed, A.A. (2001): Microbiological evaluation of some dairy desserts sold by dairy shops and served at some restaurants in Assiut city. Assuit Vet Med J, 45:62-65.

[21] Marwa, A.M.N.; Ahmed, A.A.H.; Amal, A.A. and Enas, E.M. (2004): Microbiological evaluation of some locally manufactured dairy desserts in Assiut city. M.V.Sc. Thesis, Fac. Vet. Med., Assiut Univ.

[22] El-Bagoury, A.M. (1996): Bacteriological quality of market ice cream. Vet Med J,44(2):203-207.

[23] Sobeih, A.M.K.; Al-Hawary, I.I. and Aman, I. (2002): Microbiological quality of milk and ice-cream sold in Kafr ElShikh and Gharbia governorates. Minufyia Vet J, 2(1):79-89.

[24] Mohammed, G.M.; El-Ghiaty, H.A. and Riad, E.M. (2013): Prevalence of enteric bacteria producing toxins in ice-cream and kareish cheese in Port-Said markets. Assiut Vet Med J, 59(136):16-21. 
[25] Hussein, M.F.; Sadek, O.A. and El Taher, S.G. (2015): Occurrence of Bacillus cereus and Staphylococcus aureus organisms in some dairy desserts. Assiut Vet Med J, 61(145):160-165.

[26] Altaf, M.; Iqbal, A.; Ahmad, M.; Hussain, S.; Ahmad, R. and Willayaty, M. (2012): Study of enterotoxigenicity of Bacillus cereus emetic strain by skin vasopermeability reaction in rabbits and poultry. Int Pharma Bio Sci, 3(2):166172.

[27]Salehian, M.; Salehifar, E.; Esfahanizadeh, M.; Karimzadeh, L.; Rezaei, R. and Molanejad, M. (2013): Microbial contamination in traditional ice-cream and effective factors. Mazand Univ Med Sci J, 23(99):28-33.

[28] AL-Ashmawy, A. M.; El-Ebeedy, A.A.; El-Gamal, A.M. and Youssef, S.M. (1996): Occurrence and enumeration of Bacillus cereus in Egyptian dairy desserts. Assiut Vet Med J, 36 (71):117124.

[29] Mathews, S.; Ngoma, L.; Gashe, B. and Mpuchane, S. (2013): Assessment of pathogenic bacteria from ice cream and ice pop sold in Gaborone, Botswana. Studies on Ethno-Medicine, 7(3):195203.

[30] Abdel-Hameed, K. G. and El-Malt, L. M. (2009): Public health hazard of staphylococcus aureus isolated form raw milk and ice cream in Qena governorate. Assiut Vet Med J, 55 (121):191-200.

[31] Fadel, H.M. and Ismail, J. (2009): Prevalence and significance of Staphylococcus aureus and Enterobacteriaceae species in selected dairy products and handlers. Int J Dairy Sci, 4(3):100-108.

[32] Zakary, E.M.; Nassif, M.Z. and Mohammed, G.M. (2011): Detection of Staphylococcus aureus in bovine milk and its Product by real time PCR assay.
Global J Biotech Biochem, 6(4) :171177.

[33] Sina, H.; Baba-Moussa, F.; Kayodé, A.P.; Noumavo, P.A.; Sezan, A.; Hounhouigan, J.D.; Kotchoni, S.O.; Prévost, G. and Baba-Moussa, L. (2011): Characterization of Staphylococcus aureus isolated from street foods: Toxin profile and prevalence of antibiotic resistance. J Appl Biosci, 46:3133-3143.

[34] Tang, J.; Zhang R.; Chen, J.; Zhao, Y.; Tang, T.; Yue, H.; Li, J.; Wang, Q. and Shi, H. (2015): Incidence and characterization of Staphylococcus aureus strains isolated from food markets. Annals Microbiol, 65(1):279286.

[35] Cho, Y.S.; Wang, H.J.; Lee, J.Y.; Lee, D.Y. and Shin, D.B. (2013): Prevalence and characterization of Staphylococcus aureus pathogenic factors isolated from Korean rice cakes. Food Sci Biotechnol, 22 (4):1153-1159.

[36] Egyptian Standards (1993): Milk and Dairy products. Part I: Ice-cream. Egyptian Organization for Standardization and Quality Control. EOS: 1185.

[37] World Health Organization "WHO" (1996): Microbiological quality of icecreams. International Digest of Health Legislation, 47(1):52.

[38] International Dairy Federation "IDF" (1996): Bacteriological quality of raw milk. 41 Square Vergote B 103, Brussels, Belgium.

[39] De Luca, G.; Zanetti, F. and Stamp, S. (1997): Staphylococcus aureus in dairy products in the Bologna area. Int $\mathbf{J}$ Food microbial, 35(3):267-270.

[40] Katsuda, K.; Hata, E. and Kobayashi, H. (2005): Molecular typing of Staphylococcus aureus isolated from bovine mastitic milk on the basis of toxin genes and coagulase gene 
polymorphisms. Vet Microbiol, 105: 301-305.

[41] Morandi, S.; Brasca, M.; Lodi, R.; Cremonesi, P. and Castiglioni, B. (2007): Detection of classical enterotoxins and identification of enterotoxin genes in Staphylococcus aureus from milk and dairy products. Vet Microbiol, 124(1): 66-72.

[42] Madahi, H.; Rostami, F.; Rahimi, E. and Dehkordi, F.S. (2014): Prevalence of entreotoxigenic Staphylococcus aureus isolated from chicken nugget in Iran. Jundishapur J Microbiol, 7(8):10237.

\section{الملخص العربي}

تقييم الجودة البكتيريولوجية لبعض الحلوى اللبنية المصنعة محليا و المباعة فى مدينة بنى سويف مع تحديد السموم المعوية

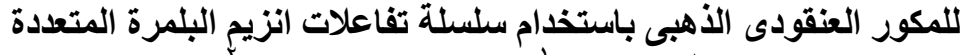

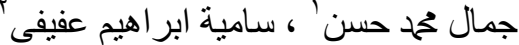

$$
\begin{aligned}
& \text { 'قسم الرقابة الصحية على الاغذية ـ كلية الطب البيطرى - جامعة بنى سويف } \\
& \text { r قسم الميكروبيولوجى ـ معهد بحوث صحة الحيوان }
\end{aligned}
$$

تضمن البحث فحص ه V عينة من الايس كريم والارز باللبن و المهلبية (0 ب عينة من كل منتج) جمعت عشو ائيا من اماكن

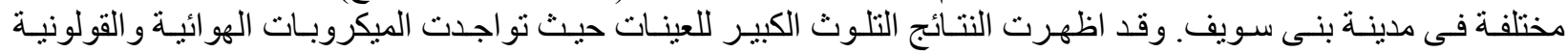

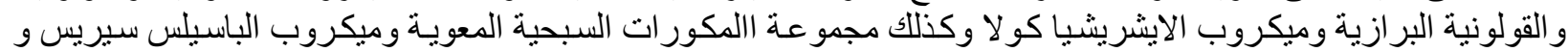

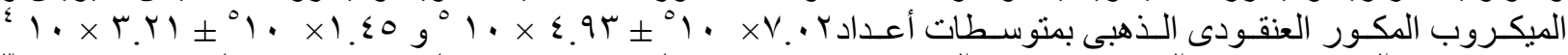

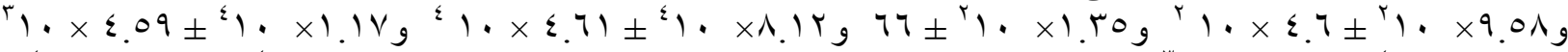

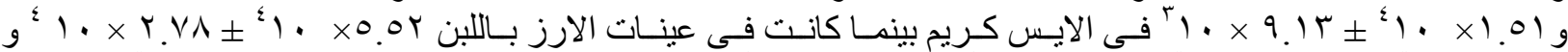

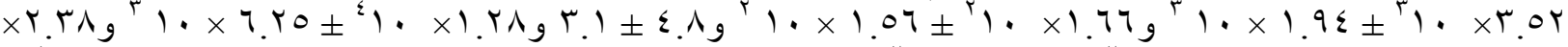

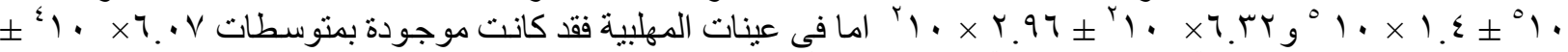

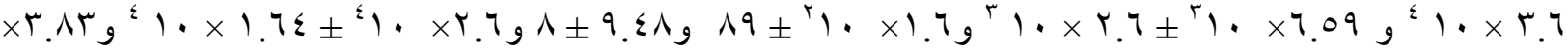
• العتر ات المعزولة من ميكروب المكور العنقودى الذهبى باستخدام سلسلة تفاعلات انزيم البلمرة المتعدد حيث وجد كل من من جينى see sea

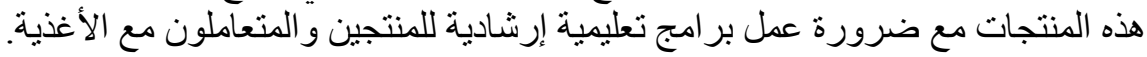

